Widi Puspa Sari, Adil Mubarak| Efektivitas Penertiban Penambangan Emas Ilegal di Kabupaten Dharmasraya

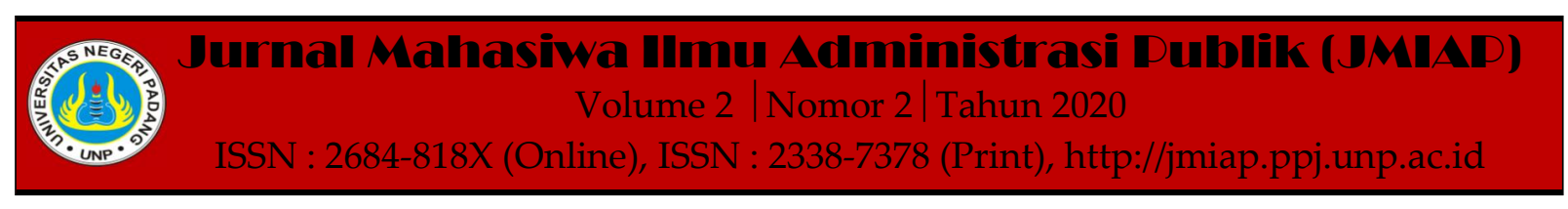

\title{
EFEKTIVITAS PENERTIBAN PENAMBANGAN EMAS ILEGAL DI KABUPATEN DHARMASRAYA
}

\author{
Widi Puspa Sari ${ }^{1(a)}$, Adil Mubarak ${ }^{2(b)}$ \\ ${ }^{1}$ Jurusan Ilmu Administrasi Negara, Universitas Negeri Padang \\ ${ }^{2}$ Jurusan Ilmu Administrasi Negara, Universitas Negeri Padang \\ a)widipuspas8@gmail.com, ${ }^{b)}$ adilmubarak@fis.unp.ac.id
}

\begin{abstract}
This articles describes the effectiveness of procedure control of ilegal gold mining activities in Dharmasraya distric. Researcher uses the theory according to Tangkilisan about an indicator of the effectiveness. The research method used qualitative descriptive. Informan in this research using purposive sampling technique. In the data collection uses by interview, observation, and documentation technique. The result research explain that the effectiveness the ilegal gold mining control in the Dharmasraya distric has not been implemented opportune and optimally. It shows there are still many problems. Such as there are not clarity of the purpose and strategy, special program, planning, policy are not written and supervision system has been not optimally. This causes the control does not go as expexcted. The causative factors of ilegal gold mining control can include by internal and external factors. Internal factors are lack of human resources, budget, and facilities. While eksternal factors are low of community participation, location far away, and leakage information. That is the reason why the effectiveness of the ilegal gold mining control in the Dharmasraya distric has not gone well.
\end{abstract}

Keywords : Effectiveness, Control, Ilegal, Dharmasraya

Corresponding author. Email.widipuspas8@gmail.com,adilmubarak@fis.unp.ac.id

How to cite this article. Sari, W. Puspa \& Mubarak, A. (2020). Efektivitas Penertiban Penambangan Emas Ilegal di Kabupaten Dharmasraya. Jurnal Mahasiwa Ilmu Administrasi Publik (JMIAP) Jurusan Ilmu Administrasi Negara Fakultas Ilmu Sosial Universitas Negeri Padang, Volume 2 (2), Hal. 62-69. http://jmiap.ppj.unp.ac.id

ISSN : 2684-818X (Online), ISSN : 2338-7378 (Print)

Copyright $\bigcirc 2020$. Published by Pusat Kajian-Pemberdayaan dan Pelayanan Masyarakat (PK-P2M) FIS UNP Padang 


\section{PENDAHULUAN}

Bahan galian tambang merupakan salah satu kekayaan yang dimiliki Indonesia. Baik itu emas, batu bara, pasir, nikel, tembaga dan lain sebagainya. Dewasa ini kegiatan pertambangan menjadi kegiatan yang cukup menjanjikan. Banyak masyarakat yang menggantungkan kehidupannya dalam sektor tambang terutama emas. Termasuk juga daerah Kabupaten Dharmasraya. Kabupaten Dharmasraya merupakan kabupaten hasil pemekaran dari Kabupaten Sijunjung. Kegiatan pertambangan di Kabupaten Dharmasraya merupakan kegiatan yang sudah dilakukan sejak nenek moyang dahulu. Awalnya kegiatan itu hanya dilakukan secara tradisional dengan cara mengindang. Keberadaan bahan galian tambang menjadi penghasilan yang cukup yang didapatkan oleh masyarakat sekitar selain sektor pertanian dan sektor perkebunan.

Setelah Dharmasraya menjadi Kabupaten pemekaran tahun 2004, masyarakat sedikit demi sedikit mulai beralih menggunakan alat-alat yang canggih. Aktivitas penambangan mulai dilakukan dengan manggunakan mesin modern seperti eksavator, mesin dompeng, dan kapal penyedot. Selain itu kegiatan tersebut juga dilakukan secara besarbesaran yang mana tidak hanya sungai dan pinggir sungai yang menjadi sasarannya tapi pemakaian lahan produktif pun turut beralih fungsi menjadi area pertambangan. Sehingga banyak terjadi kerusakan lahan akibat kegiatan pertambangan yang dilakukan oleh oknum-oknum tersebut. Luas kerusakan lahan bekas tambang hingga Juli 2020 telah mencapai 1359,7 Ha dengan urutan yang paling tinggi terdapat di Pulau Punjung sebanyak 795,53 Ha, Asam Jujuhan 139,84 Ha, dan Sitiung 135,86 Ha. Ketiga daerah tersebut merupakan daerah yang banyak didapati kerusakan lahan bekas tambang. Berikut gambar kerusakan lahan bekas tambang di Kabupaten Dharmasraya.

\section{Gambar 1. Kerusakan Lahan Bekas Tambang di Kabupaten Dharmasraya}

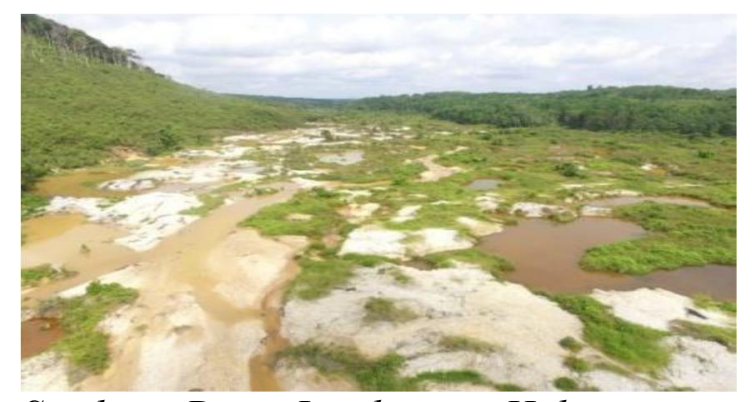

Sumber: Dinas Lingkungan Hidup

Kabupaten Dharmasraya

Saat ini aktivitas pertambangan di Kabupaten Dharmasraya telah bergeser guna menjadi kegiatan yang ilegal. Selain menggunakan mesin eksavator, dompeng, kapal penyedot, para penambang juga menggunakan zat-zat kimia seperti merkuri atau air raksa. Karena tergiur untuk mendapatkan hasil yang instan dan banyak, para penambang justru tidak lagi memperhatikan bahaya penggunaan zat-zat kimia dalam proses tambang. Buruknya penggunaan zat-zat kimia dibuktikan dengan telah mengeruhnya air sungai yang dulu sering digunakan warga setempat untuk mencuci, memasak, minum, dan sebagainya. Kerusakan lahan bekas tambang tersebut dapat menimbulkan permasalahan baru seperti longsor, banjir, krisis air bersih, wabah penyakit serta dapat menghilangkan mata pencaharian masyarakat apabila tidak segera dilakukan perbaikan (Mubarak, 2019).

Kegiatan pertambangan ilegal bukan perihal yang baru kita dengar. Dinas ESDM Provinsi Sumatera Barat menjelaskan bahwa kegiatan pertambangan emas ilegal di Kabupaten Dharmasraya memang cukup marak. Titik-titik praktik tambang emas ilegal itu selalu ada dan tidak bisa diperkirakan. Wajar saja karena daerah Dharmasraya marupakan salah satu daerah yang berpotensi kaya akan bahan tambang. Banyak para penambang yang tidak mengantongi izin dan tidak melakukan kegiatan sesuai kaidah tambang. Selain merusak lahan, dan mencemari lingkungan, kegiatan ilegal tersebut justru juga 
merugikan pemerintah daerah karena para penambang tidak membayar pajak kepada pemerintah yang mana pajak tersebut juga digunakan pemerintah daerah untuk kemakmuran rakyat secara keseluruhan.

Aktivitas pertambangan ilegal ini sebenarnya sudah dilakukan penertiban oleh pihak kepolisian dan Satpol PP. Berikut tabel kegiatan PETI tahun 2020.

Tabel 1. Kegiatan PETI Tahun 2020

\begin{tabular}{|c|c|c|}
\hline No & Bulan & $\begin{array}{c}\text { Penambang yang } \\
\text { Tertangkap }\end{array}$ \\
\hline 1 & $\begin{array}{l}\text { Maret } \\
2020\end{array}$ & $\begin{array}{l}\text { Zahirman, } \\
\text { Eki Yandra }\end{array}$ \\
\hline 2 & $\begin{array}{l}\text { Juni } \\
2020\end{array}$ & $\begin{array}{l}\text { Tidak ada penambang } \\
\text { yang tertangkap karena } \\
\text { penambang berhasil } \\
\text { melarikan diri }\end{array}$ \\
\hline 3 & $\begin{array}{l}\text { Juni } \\
2020\end{array}$ & $\begin{array}{l}\text { - Suroso, } \\
\text {-Suparlan, } \\
\text {-Sukamto, } \\
\text {-M.Zainuri }\end{array}$ \\
\hline 4 & Juli 2020 & $\begin{array}{l}\text { Satu orang Wali } \\
\text { Nagari Tiumang, } \\
6 \text { orang pekerjanya }\end{array}$ \\
\hline
\end{tabular}

Sumber : Kapolres Dharmasraya

Berdasarkan tabel di atas dapat kita ketahui bahwa masih banyaknya pelaku PETI di daerah kabupaten Dharmasraya. Meskipun sudah dilakukan penertiban oleh pihak yang berwenang, namun kegiatan pertambangan emas ilegal tetap saja masih berlangsung. Hari ini ditertibkan, aktivitas itu akan kembali lagi terulang esok atau lusanya. Penertiban aktivitas pertambangan emas ilegal sepertinya belum mencapai titik maksimal. Karena kegiatan itu masih terus menjamur dan tak pernah ada habishabisnya.

Dari permasalahan tersebut, penulis ingin mengetahui bagaimana efektivitas penertiban penambangan emas ilegal di Kabupaten Dharmasraya dan faktor yang mempengaruhi efektivitas penertiban.

\section{TINJAUAN PUSTAKA \\ Konsep Efektivitas}

Menurut (Handoko, 2000) efektivitas didefinisikan sebagai suatu usaha untuk melakukan tujuan yang tepat dengan mengandalkan peralatan yang ada dan faktor pendukung lainnya demi terwujudnya tujuan yang telah ditetapkan sebelumnya.

Sedangkan menurut (Siagian, 2003) efektivitas merupakan perwujudan sasaran yang memperlihatkan sejauh mana sasaran tersebut telah tercapai. Jadi efektivitas berkaitan erat dengan pencapaian tujuan yang telah ditetapkan yang mana efektivitas tersebut dapat memprediksi mengenai keberhasilan suatu organisasi dalam melaksanakan suatu kegiatan.

Pengukuran terhadap efektivitas dapat dilihat dengan menggunakan beberapa indikator tergantung dari sudut peneliti dan bagian apa yang hendak diteliti. Untuk melihat efektivitas penertiban penambangan emas ilegal di Kabupaten Dharmasraya, peneliti menggunakan teori (Tangkilisan, 2005) yang mana indikator efektivitas tersebut yaitu :

1) Kejelasan terhadap tujuan;

2) Kejelasan strategi tercapainya tujuan;

3) Proses analisa dan perumusan kebijakan:

4) Perencanaan yang matang;

5) Penyusunan program yang tepat;

6) Tersedianya sarana dan prasarana kerja;

7) Sistem pengawasan yang bersifat mendidik.

\section{Konsep Penertiban}

Menurut (Frinaldi, 2019) tertib didefinisikan sebagai refleksi suatu sikap disiplin, konsisten, efisien, teratur dan tidak menimbulkan kegaduhan. Untuk menciptakan hal itu pemerintah harus turun aktif dalam bidang kehidupan masyarakat, khususnya sosial dan ekonomi. Sedangkan penertiban merupakan proses atau cara yang digunakan untuk mangatur sesuatu yang tidak sesuai dengan aturan. 
Menurut (Soekanto, 2012) dengan dilakukannya penertiban akan terwujud sikap :

1) Sadar terhadap hukum

Untuk dapat menaati suatu peraturan yang telah dibuat diperlukan kesadaran atas hukum itu sendiri.

2) Pengendalian Sosial

Berhubungan dengan segala bentuk proses, baik yang direncanakan, bersifat mendidik, atau mengajak masyarakat yang mana keseluruhan proses tersebut tidak mengandung unsur kekerasan atau paksaan.

\section{Konsep Pertambangan Ilegal}

Pertambangan merupakan tahapan kegiatan dalam rangka penelitian, pengolahan dan pengusahaan mineral atau batu bara yang meliputi penyelidikan umum, eksplorasi, studi kelayakan konstruksi, penambangan, pengolahan dan pemurnian, pengangkutan dan penjualan, serta kegiatan pasca tambang (UndangUndang Nomor 4 tahun 2009).

Sedangkan pertambangan ilegal dimaksudkan sebagai kegiatan yang dilakukan oleh badan hukum atau perseorangan yang mana kegiatannya tidak memiliki izin dari pemerintah sesuai peraturan perundangan yang berlaku (Sallim, 2005).

Kegiatan pertambangan ilegal atau yang biasa disebut pertambangan tanpa izin cenderung memiliki banyak dampak negatif seperti kerusakan lahan bekas tambang, pencemaran lingkungan, dan juga merugikan pemerintah. Pasalnya kegiatan tambang ilegal ini tidak melakukan kegiatan berdasarkan Standar Operasional Prosedur yang berlaku atau tidak menerapkan kegiatan tersebut berdasarkan kaidah-kaidah pertambangan secara benar.

\section{METODE PENELITIAN}

Metode penelitian adalah kualitatif deskriptif. Lokasi penelitian dilakukan di daerah Kabupaten Dharmasraya. Pemilihan informan menggunakan teknik purposive sampling. Data dikumpulkan melalui studi dokumentasi dan metode wawancara. Teknik triangulasi digunakan untuk menguji keabsahan data yang menggunakan pihak luar untuk dijadikan pembanding sehingga bisa ditarik kesimpulan.

\section{HASIL DAN PEMBAHASAN}

Efektivitas Penertiban Penambangan Emas Ilegal di Kabupaten Dharmasraya

Penuntasan terhadap kegiatan pertambangan emas ilegal di Kabupaten Dharmasraya mengacu kepada UndangUndang Nomor 4 Tahun 2009 tentang Pertambangan Mineral dan Batu Bara, kemudian Peraturan Daerah Nomor 3 Tahun 2012 tentang Pengelolaan Usaha Pertambangan Mineral dan Batu Bara dan juga SK Bupati Dharmasraya Nomor : 189.1/153/KPTS-BUP/2011 tentang Pembentukan Tim Penertiban Kegiatan PETI.

Menurut (Tangkilisan, 2005) untuk mengukur suatu efektivitas digunakan beberapa indikator yaitu : 1) Kejelasan terhadap tujuan 2) Kejelasan strategi tercapainya tujuan. 3)Proses analisa dan perumusan kebijakan. 4)Perencanaan yang matang. 5) Penyusunan program yang tepat. 6) Tersedianya sarana dan prasarana kerja. 7) Sistem pengawasan yang bersifat mendidik.

\section{Kejelasan terhadap Tujuan}

Menurut (Steers, 1985) tujuan merupakan bagian puncak dari usaha yang hendak dilakukan. Upaya pencapaian tujuan dimaksudkan sebagai suatu proses untuk mengetahui apakah tujuan tersebut berjalan dengan baik atau tidak.

Kejelasan terhadap tujuan merupakan pondasi awal yang harus dibentuk dan disepakati secara bersama. Untuk hal itu tentu harus dirumuskan tujuan yang jelas yang tertuang dalam bentuk kebijakan, peraturan bupati, peraturan daerah atau semacamnya. Sehingga para stakeholders yang memiliki tugas dan tanggung jawab terkait penertiban ini bisa memiliki tujuan yang sama dan terarah dalam melaksanakan tugas. Namun kenyataannya tujuan utama 
dari kegiatan penertiban penambangan emas ilegal di Kabupaten Dharmasraya belum tersusun dengan jelas karena kegiatan tersebut tidak dirumuskan secara komprehensif dan tidak terdokumentasi secara tertulis. Padahal permasalahan terkait penambangan emas ilegal ini harusnya mendapatkan perhatian yang cukup serius dari berbagai sektor lembaga.

Selanjutnya, karena tidak adanya kejelasan tujuan yang terdokumentasi secara tertulis, kegiatan penertiban yang sifatnya lintas lembaga ini justru memiliki tujuannya masing-masing dari lembaga terkait. Alhasil tujuan kegiatannya tidak terkoordinir dengan baik.

\section{Kejelasan Strategi Tercapainya Tujuan}

Dalam proses pencapaian tujuan juga sangat diperlukan sebuah strategi. Menurut (Terry G. , 2013) strategi didefenisikan sebagai cara terbaik yang dipilih dengan memanfaatkan sumber daya untuk pencapaian tujuan. Berdasarkan penelitian yang telah dilakukan, kegiatan ini juga tidak memiliki strategi yang jelas sama halnya dengan kejelasan terhadap tujuan sebelumnya. Aturannya strategi menjadi hal pendukung untuk pencapaian tujuan secara efektif. Strategi juga harus dirancang bersamaan dengan tujuan agar kegiatannya bisa lebih terarah. Dalam pembentukan strategi, harus terrsusun secara konkrit tugas serta siapa saja lembaga yang akan melaksanakan tugas itu.

Strategi yang digunakan tim penertiban hanya timbul dari keseharian tugas atau spontanitas saja. Strategi tersebut belum bisa dikatakan efektif karena kenyataan di lapangan tim penertiban sering merasa kecolongan ketikan melakukan razia. Meskipun dari rentang tahun 2018-2020 pihak kepolisian berhasil menangkap sebanyak 23 pelaku PETI di beberapa daerah Dharmasraya. Tapi seiring sering terjadinya kebocoran terhadap infromasi razia juga menjadi catatan penting yang harus diperhatikan tim untuk segera meminimalisir hambatan tersebut dengan membentuk dan merancang kejelasan strategi yang tertuang dalam bentuk Renstra.

\section{Proses Analisa dan Perumusan Kebijakan}

Menurut Siagian dalam (Stephanus \& dkk, 2017) kebijakan harus dapat menghubungkan tujuan-tujuan dengan usaha pelaksanaan kegiatan. Kebijakan merupakan pondasi dalam seluruh wujud aksi.

Undang-Undang Nomor 4 Tahun 2009 tentang Pertambangan Mineral dan Batu Bara merupakan acuan dasar terkait diadakannya penertiban terhadap penambangan emas ilegal di Kabupaten Dharmasraya. Tapi tidak ada kebijakan perda khusus yang membahas tentang penertiban yang dibentuk oleh pemerintah daerah. Surat Keputusan yang dibentuk oleh Bupati pun juga tidak membahas secara rinci mengenai tupoksi dari masing-masing lembaga yang terlibat di dalamnya serta Surat Keputusan juga tidak terdapat pembaharuan sejak periode Kepala Daerah tahun 2011 lalu.

Kebijakan peraturan daerah yang mengatur tentang larangan kegiatan PETI menjadi hal terpenting yang harus dirumuskan oleh pemerintah daerah. Ketiadaan peraturan daerah yang membahas tentang larangan tersebut membuat kegiatan penertiban di lapangan tidak dapat dikendalikan secara optimal.

\section{Perencanaan yang Matang}

(Tangkilisan, 2005) menjelaskan bahwa perencanaan juga termasuk bagian penting dalam mengukur efektivitas suatu organisasi. Tidak akan tercapai tujuan suatu organisasi apabila tidak memiliki perencanaan yang matang dan jelas.

Berdasarkan temuan di lapangan dapat dilihat bahwa perencanaan yang dimaksud oleh tim terkait penertiban yaitu membentuk tim, melakukan razia, menangkap pelaku, menyita Barang Bukti (BB) kemudian memberikan sanksi pidana kepada para pelaku sesuai pasal 158 Undang-Undang Nomor 4 Tahun 2009. Hal 
tersebut berhubungan dengan strategi yang mereka gunakan ketika hendak melakukan razia atau penertiban.

Menurut peneliti perencanaan tersebut juga tidak tersususn dengan jelas dan matang. Perencanaan suatu kegiatan tidak hanya sekedar membahas secara umum, tapi harus direncanakan secara detail dan menyeluruh. Perencanaan itu harusnya dituliskan secara jelas agar memudahkan pelaksanaan kegiatan. Biasanya di dalamnya memuat tujuan, strategi, pihak yang terlibat, anggaran yang dibutuhkan, sarana dan prasraana yang diperlukan, kemudian diimplementasikan dan dilakukan pengevaluasian. Pembentukan perencanaan yang matang diharapkan dapat meminimalisir potensi terjadinya tumpang tindih serta implementasi setiap kegiatan memiliki sasaran dan tujuan yang jelas.

\section{Penyusunan Program yang Tepat}

Penyusunan terhadap suatu program dalam sebuah kegiatan perlu dilakukan agar kegiatan lebih fokus dilaksanakan dan bernilai efektif. Namun sayangnya, tim penertiban tidak memiliki program khusus dan tersusun terkait penertiban penambangan emas ilegal di Kabupaten Dharmasraya. Padahal penjabaran terhadap program digunakan agar para pelaksana penertiban memiliki acuan dalam bertindak. Sehingga hal tersebut dapat mempermudah dalam proses pelaksanaan penertiban.

\section{Tersedianya Sarana dan Prasarana Kerja}

Sarana dan prasarana kerja digunakan untuk meningkatkan kapasitas kerja yang mendukung pelaksanaan penertiban. Fasilitas sarana dan prasarana yang menunjang pelaksanaan penertiban sudah cukup lengkap, hanya saja kendaraan yang bisa menembus buruknya jalan dan jauhnya medan masih tergolong minim contohnya seperti mobil double gardan, motor trail atau kendaraan roda 2 lainnya yang bisa dimasuki sampai ke TKP.

Sarana dan prasarana kerja yang digunakan tergantung lokasi medan yang ditempuh. Kalau lokasinya jauh dan memungkinkan untuk dimasuki mobil, tim akan menggunakan mobil. Tapi biasanya lokasi penambangan emas ilegal kebanyakan terdapat di pelosok-pelosok daerah hingga ke daerah-daerah hutan. Bahkan untuk menuju lokasi tersebut tidak bisa menggunakan kendaraan dan harus ditempuh dengan berjalan kaki.

\section{Sistem Pengawasan yang Bersifat Mendidik}

Menurut (Tangkilisan, 2005) sistem pengawasan ini merupakan indikator terakhir yang dinilai untuk mengukur efektivitas suatu organisasi. Berdasarkan penelitian yang dilakukan, sistem pengawasan terkait kegiatan penertiban penambangan emas ilegal di Kabupaten Dharmasraya dilakukan berdasarkan ruang lingkup aktivitas tambang dan kesepakatan tim gabungan. Kegiatan penertiban tersebut biasanya dimonitoring oleh Kapolda Sumbar, Kapolres Dharmasraya, dan Kasat Reskrim Dharmasraya. Jika penertiban tersebut bersifat gabungan, kegiatan penertiban akan diawasi langsung oleh Kapolda Sumbar. Kegiatan penertiban yang sifatnya tidak gabungan akan selalu diawasi oleh Kasat Reskrim Dharmasraya yaitu Bapak AKP. Suyanto, SH.

Berdasarkan temuan tersebut dapat diketahui bahwa kegiatan penertiban penambangan emas ilegal sudah diawasi secara efektif dan baik oleh pihak penegak hukum karena pihak penegak hukum memiliki kewenangan yang cukup kuat untuk melakukan penindakan terkait penetiban. Akan tetapi pemerintah daerah dan instansi lainnya tidak memiliki peran andil di dalamnya. Kegiatan penertiban penambangan emas liar justru dilimpahkan seluruhnya hanya kepada pihak kepolisian dan Satpol PP. Pemerintah daerah hanya sekedar menerima laporan terhadap hasil kegiatan penertiban yang dilakukan oleh tim penindakan. 
Faktor yang Mempengaruhi Efektivitas Penertiban Penambangan Emas Ilegal di Kabupaten Dharmasraya

Terdapat beberapa faktor yang mempengaruhi efektivitas penertiban penambangan emas ilegal di Kabupaten Dharmasraya, yang mana peneliti membaginya menjadi faktor internal dan faktor eksternal.

a) Faktor Internal

1) Sumber Daya Manusia

Tenaga sumber daya manusia untuk mengamankan Barang Bukti yang digunakan para pelaku tambang masih bisa dibilang minim. Para pelaku tambang menggunakan beberapa peralatan yang cukup berat dan lokasinya pun juga terpelosok.

2) Biaya atau anggaran

Setiap pelaksanaan kerja tidak akan terlepas dari yang namanya anggaran. Dalam hal ini Tim penertiban tidak memiliki dana khusus terkait penertiban PETI. Padahal kegiatan penuntasan terhadap pelaku tambang liar merupakan persoalan yang harusnya mendapat perhatian lebih.

\section{3) Sarana dan Prasarana}

Sarana dan prasarana yang digunakan tim penertiban untuk menembus buruknya jalan dan jauhnya medan yang ditempuh masih tergolong minim. Hal ini tentu akan menghambat tim penertiban dalam melaksanan tugasnya terkait penertiiban tambang emas ilegal

b) faktor eksternal

1) Partisipasi Masyarakat

Masih kurangnya kesadaran dan partisipasi masyarakat terhadap kegiatan pertambangan juga menjadi salah satu penghambat karena justru pelaku tambang tersebut kebanyakan dari masyarakat setempat.

3) Jauhnya medan yang ditempuh saat menuju lokasi.

4) Sering terjadinya kebocoran informasi mengenai razia penertiban
5) Penambangan emas ini telah dilakukan sejak dahulu oleh warga sehingga proses ini sangat sulit untuk dihentikan

\section{PENUTUP}

Berdasarkan penelitian di atas dapat disimpulkan :

1) Pelaksanaan penertiban penambangan emas ilegal di Kabupaten Dharmasraya belum berjalan secara efektif. Kejelasan tujuan yang hendak dicapai tidak tersusun dengan jelas dan tidak terdokumentasi secara tertulis sehingga para sektor lembaga yang mempunyaii tugas dan tanggung jawab terkait penertiban tidak memiliki tujuan yang sama dan terarah. Kejelasan strategi pencapaian tujuan serta bentuk perancanaan masih dirasakan belum optimal karena masih banyak terjadi kebocoran informasi mengenai razia penertiban yang akan dilakukan. Kebijakan yang digunakan pun hanya berpatokan kepada UU Nomor 4 Tahun 2009 tentang Pertambangan Mineral dan Batu Bara, tidak terdapatnya perda atau perbup khusus yang dibentuk oleh pemerintah daerah terkait penuntasan kegiatan tambang ilegal. Program penertiban juga tidak dideskripsikan dengan jelas. Program hanya dijalankan berdasarkan tupoksinya saja. Fasilitas sarana dan prasarana yang menunjang pelaksanaan penertiban juga kurang lengkap karena kendaraan yang bisa menembus buruknya jalan dan jauhnya medan yang ditempuh masih tergolong minim, serta pengawasan masih belum berjalan dengan efektif karena sistem pengawasan ketika melakukan penindakan penertiban hanya dilakukan oleh pihak kepolisian. Pemerintah daerah dan instansi terkait lainnya tidak memiliki peran andil di dalamnya.

2) Faktor penghambat dari proses penertiban yang dilakukan terbagi atas faktor internal dan faktor eksternal. Faktor internalnya adalah sumber daya manusia yang tidak mencukupi, anggaran khusus mengenai penertiban 
penambangan emas ilegal juga tidak dianggarkan dengan jelas. Masih minimnya jumlah sarana dan prasarana membuat pelaksanaan penertiban penambangan emas liar juga kurang optimal. Faktor eksternalnya yaitu masih kurangnya kesadaran dan partisipasi masyarakat, jauhnya lokasi medan yang ditempuh serta seringnya terjadi kebocoran informasi razia yang akan dilakukan dan kegiatan tambang merupakan kegiatan yang sudah dilakukan turun temurun sehingga cukup sulit untuk dihentikan

\section{DAFTAR KEPUSTAKAAN}

Frinaldi, A. (2019). Policy Management to Development Tourism Work Culture Consciousness and Increasing Visiting People's Satisfaction. Jurnal Studi Pemerintah.

Handoko. (2000). Manajemen Edisi 2.

Yoogyakarta: BPFE.

Mubarak, A. (2019). Peran Pemerintah

Kabupaten Dharmasraya dalam

Memperbaiki Kerusakan Lahan Bekas

Tambang. Jurnal Perspektif : Jurnal

Kajian Sosiologi dan Pendidikan,

Volume 2 Nomor 3.

Sallim, H. (2005). Hukum Pertambangan di Indonesia. Jakarta: PT Raja

Grafindo Persada.

Siagian. (2003). Administrasi

Pembangunan: KOnsep Dimensi dan

Strateginya. Jakarta: PT : Bumi

Aksara.

Soekanto. (2012). Pokok-Pokok Sosiologi

Hukum. Jakarta: Rajawali Press.

Steers. (1985). Efektivitas Organisasi.

Jakarta: Erlangga.

Stephanus, \& dkk. (2017). Efektivitas

Pemungutan Retribusi Izin Trayek

pada Badan Pelayanan Perizinan
Terpadu Kota Manado. Jurnal EMBA.

Tangkilisan. (2005). Manajemen Publik. Jakarta: PT Grafindo Persada.

Terry, G. (2013). Prinsip-Prinsip

Manajemen. Jakarta: PT Bumi Aksara. 